\title{
STRATEGI PENGELOLAAN PENAMBANGAN PASIR LAUT YANG BERKELANJUTAN (STUDI KASUS PULAU TUNDA, PROVINSI BANTEN)
}

\section{STRATEGY OF SUSTAINABLE SEA-SAND MINING (A CASE STUDY IN TUNDA ISLAND, BANTEN)}

\author{
Wawan Wahyudi ${ }^{*}$, Etty Riani², dan Syaiful Anwar ${ }^{3}$ \\ ${ }^{1}$ Program Studi Pengelolaan Sumberdaya Alam dan Lingkungan, FPIK-IPB, Bogor \\ ${ }^{2}$ Departemen Managemen Sumberdaya Perairan, FPIK-IPB, Bogor \\ ${ }^{3}$ Departemen Ilmu Tanah dan Sumberdaya Lahan, Faperta-IPB, Bogor \\ *E-mail:wwnwhd@gmail.com
}

\begin{abstract}
Sea-sand mining in small island, such as Tunda Island, was potential to cause environmental degradation. The aim of this research was to find the sustainable strategy management of sea sand mining in Tunda Island. This research was conducted by interview the expert respondents that selected purposively and answering the questionnaires. The data obtained from questionnaires were analyzed by AHP. The result showed the dominant factors that must be considered for sustainable management of sand mining were natural resources, government policy, and socio-economic of community. Stakeholders also play an important role to be considered for sustainable sand mining including the government, bussinessman, communities and law enforcers. While the objectives to be prioritized for sustainable sea sand mining are minimize the environmental degradation, ecosystem recovery and enhancement of beauty competitiveness of small island waters area where sand mining occur. The most important strategic alternative priorities for sustainable sand mining management are sand mining policy revision, law enforcement and the legal consequences, and eco friendly technology for sand mining.
\end{abstract}

Keyword: AHP, management, sand mining, suistainable, strategy, Tunda Island

\begin{abstract}
ABSTRAK
Penambangan pasir laut di pulau-pulau kecil, seperti Pulau Tunda, Kepulauan Seribu, Jakarta berpotensi mengakibatkan degradasi lingkungan. Penelitian ini bertujuan untuk mendapatkan strategi pengelolaan penambangan pasir laut di perairan Pulau Tunda yang berkelanjutan. Penelitian ini dilakukan wawancara dengan responden ahli yang dipilih secara purposive, dengan bantuan kuesioner. Data yang diperoleh dianalisis dengan AHP. Hasil penelitian menunjukkan bahwa faktor dominan yang harus diperhatikan pada pengelolaan penambangan pasir laut agar menjadi berkelanjutan adalah sumberdaya alam, kebijakan pemerintah, dan sosial ekonomi masyarakat. Stakeholders yang harus diperhatikan agar penambangan pasir laut menjadi berkelanjutan adalah pemerintah, pengusaha, masyarakat dan penegak hukum. Adapun tujuan yang harus didahulukan agar penambangan pasir laut berkelanjutan, yakni reduksi degradasi lingkungan, pemulihan ekosistem dan peningkatan daya saing keindahan wilayah perairan pulau kecil yang pasirnya ditambang. Prioritas alternatif strategi yang paling penting dalam pengelolaan penambangan pasir laut agar menjadi berkelanjutan adalah revisi kebijakan penambangan pasir laut, penegakan hukum dan sangsinya, serta teknologi penambangan pasir ramah lingkungan.
\end{abstract}

Kata kunci: AHP, pengelolaan, penambangan pasir laut, berkelanjutan, strategi, Pulau Tunda

\section{PENDAHULUAN}

Kawasan pesisir dan pulau-pulau kecil merupakan ekosistem yang memiliki potensi sumberdaya yang sangat besar. Sumber daya yang terdapat di dalamnya antara lain adalah sumber daya hayati, sumber daya non hayati; sumber daya buatan, 
dan jasa-jasa lingkungan. Sumber daya hayati yang ada di perairan pesisir dan pulaupulau kecil antara lain adalah ikan, terumbu karang, padang lamun, mangrove dan biota laut lain. Sumber daya non hayati meliputi pasir, air laut, mineral dasar laut. Sumber daya buatan meliputi infrastruktur laut yang terkait dengan kelautan dan perikanan, dan jasa-jasa lingkungan berupa keindahan alam, permukaan dasar laut tempat instalasi bawah air yang terkait dengan kelautan dan perikanan serta energi gelombang laut yang terdapat di wilayah pesisir. Salah satu kabupaten yang mempunyai wilayah pesisir dan pulau-pulau kecil adalah Kabupaten Serang.

Kabupaten Serang merupakan salah satu dari enam kabupaten/kota di Provinsi Banten, yang terletak di ujung barat bagian utara Pulau Jawa dan merupakan pintu gerbang utama yang menghubungkan Pulau Sumatera dengan Pulau Jawa dengan jarak $70 \mathrm{~km}$ dari ibu kota negara. Secara geografis, wilayah Kabupaten Serang terletak pada koordinat $5^{\circ} 50^{\prime}-6^{\circ} 2^{\prime} \mathrm{LS}$ dan $105^{\circ} 7^{\prime}-106^{\circ}$ $22^{\prime}$ BT.

Wilayah pesisir Kabupaten Serang mempunyai panjang garis pantai $120 \mathrm{~km}$. Perairan ini di sebelah utara berbatasan dengan perairan Laut Jawa dan di sebelah barat berbatasan dengan perairan Selat Sunda. Kekayaan alam laut dan sumberdaya pesisir yang dimiliki wilayah ini antara lain berupa sumberdaya perikanan, sumberdaya hayati seperti mangrove (hutan bakau), terumbu karang, padang lamun, termasuk bahan tambang lainnya yang memiliki nilai ekonomi tinggi. Salah satu bahan tambang yang memiliki nilai ekonomis dan saat ini dilakukan eksploitasi dalam jumlah yang cukup besar di perairan ini adalah pasir laut.

Menurut Prihantono et al. (2016) tingginya potensi pasir laut dikarenakan wilayah ini berada pada pertemuan Selat Karimata dan Selat Sunda yang membawa sedimen-sedimen dari daerah sekitar selat tersebut. Banyaknya sungai besar yang bermuara di pantai utara Kabupaten Serang juga menjadikan perairan di pesisir Kabupaten Serang memiliki sedimentasi yang tinggi. Oleh karena itu maka sebaran ketebalan pasir laut di Kabupaten Serang berkisar antara 0,5-13,8 m. Menurut Saraswati (2005), Kabupaten Serang memiliki potensi cadangan stok pasir laut layak tambang mencapai 3.7 miliar $\mathrm{m}^{3}$.

Tingginya potensi pasir laut di Kabupaten Serang, membuat sejak tahun 2003, Pemerintah Daerah Kabupaten Serang, mengusahakan penambangan pasir laut di wilayahnya. Hal ini sekaligus merupakan respon dari Pemerintah Kabupaten Serang untuk ikut serta memenuhi permintaan pasir urug, untuk memenuhi permintaan pasir untuk pembukaan lahan baru ke arah pesisir di berbagai wilayah, khususnya di DKI Jakarta (Kusumawati, 2008).

Salah satu wilayah pertambangan pasir laut di Kabupaten Serang adalah Perairan Pulau Tunda. Pulau Tunda secara administratif terletak di Kecamatan Tirtayasa dengan posisi geografis berada pada kordinat $5^{\circ} 48^{\prime} 43$ “ $\mathrm{LS}$ dan $106^{\circ} 16^{\prime} 47^{\text {“ }}$ BT dengan luas 289,79 ha. Penambangan pasir laut di wilayah perairan Pulau Tunda di satu sisi dapat menjadi sumber pendapatan daerah, namun di sisi lain juga dapat mengakibatkan terjadinya kerusakan lingkungan. Hal ini berpotensi untuk mengancam kelestarian sumberdaya hayati yang ada di dalamnya, yang dapat merugikan masyarakat setempat. Namun penelitian terkait penambangan pasir tersebut yang dilakukan hanya sebatas menilai volume pasir yang boleh ditambang dan nilai ekonomisnya yang dilakukan oleh Kusumawati (2008). Penelitian hidrodinamika yang terkait dengan penambangan pasir laut dilakukan oleh Prihantono et al. (2007), serta pada penelitian dampak penambangan pasir terhadap rajungan dilakukan oleh Parluhutan (2007), namun penelitian yang terkait dengan bagaimana memformulasi strategi untuk pengelolaan penambangan pasir yang berkelanjutan belum pernah dilakukan. Oleh karena itu perlu dilakukan penelitian mengenai strategi 
pengelolaan penambangan pasir laut di perairan Pulau Tunda, Kabupaten Serang yang berkelanjutan. Berdasarkan hal tersebut, maka penelitian ini bertujuan untuk merumuskan strategi pengelolaan kegiatan penambangan pasir di wilayah perairan Pulau Tunda.

\section{METODE PENELITIAN}

\subsection{Waktu dan Tempat Penelitian}

Penelitian ini dilaksanakan pada bulan Juni hingga bulan Agustus 2017. Penelitian ini dilakukan di wilayah perairan Pulau Tunda, Kabupaten Serang-Provinsi Banten, yang merupakan salah satu lokasi penambangan pasir laut di Provinsi Banten.

\subsection{Bahan dan Alat}

Pengumpulan data primer dilakukan melalui pengamatan langsung di lapangan tentang pelaksanaan penambangan pasir. Adapun data yang dikumpulkan adalah proses penambangan pasir laut, personil penambang pasir, informasi kesejahteraan masyarakat Pulau Tunda, sara bagi hasil keuntungan dengan masyarakat, dsb. Selain pengamatan langsung pada penelitian ini juga dilakukan wawancara mendalam dengan para stakeholder yang telah ditentukan secara purpossive sampling. Pengambilan data dari para stakeholder dilapang dilakukan dengan cara melakukan wawancara mendalam pada responden ahli yang memenuhi persyaratan yang ditentukan (stakeholder), dengan bantuan kuesioner perbandingan berpasangan. Selain itu juga pada penelitian ini, stakeholder juga diminta untuk menentukan faktor-faktor yang berpengaruh terhadap penambangan pasir di lapang. Alat bantu yang digunakan untuk wawancara dengan responden terpilih adalah kuesioner.

\subsection{Metode Penelitian}

Analisa perangkingan variabel dengan menggunakan metode AHP dilakukan untuk mendapatkan strategi pengelolaan dampak lingkungan pertambangan pasir laut. AHP adalah salah satu metode yang digunakan membantu menyelesaikan masalah penambangan pasir laut yang mengandung banyak kriteria (Multi-Criteria Decision Making) yang dipelopori oleh Saaty pada tahun 1970, pada penelitian ini faktor yang berpengaruh ditentukan dari hasil wawancara mendalam dengan para stakeholder penambangan pasir laut. Adapun yang dimaksud dengan stakeholder menurut Hovland (2005) adalah orang maupun kelompok yang memiliki kepentingan atau terkena dampak dari suatu kegiatan. Menurut Golder et al. (2005) stakeholder merupakan penerima dampak positif atau negatif dari suatu kegiatan. Menurut Crosby (1992) stakeholder yang diwawancara hendaknya stakeholder utama, yaitu pihak yang berkepentingan langsung dalam kegiatan. Oleh karena itu maka pemilihan responden dilakukan secara purposive.

\subsection{Analisa Data}

AHP digunakan dalam penelitian ini karena terdapat lebih dari satu kriteria yang perlu dipertimbangkan terkait pemilihan faktor utama pada pertambangan pasir laut. Pada dasarnya, AHP bekerja dengan cara memberi prioritas kepada alternatif yang penting mengikuti kriteria yang telah ditetapkan (Marimin, 2004). AHP juga memecah berbagai peringkat struktur hirarki berdasarkan tujuan, kriteria, sub-kriteria, dan pilihan atau alternative (decompotition). AHP juga memperkirakan perasaan dan emosi (psikologi manusia) sebagai pertimbangan dalam membuat keputusan. Suatu set perbandingan secara berpasangan (pairwise comparison) kemudian digunakan untuk menyusun peringkat elemen yang diperbandingkan.

Langkah-langkah dasar dalam analisis AHP pada penelitian ini adalah mendefinisikan persoalan dan pemecahan masalah yang diinginkan. Selanjutnya membuat struktur hirarki secara menyeluruh dan membuat matriks berpasangan untuk pengaruh setiap elemen terhadap elemen yang setingkat di atasnya yang didasarkan 
pada judgement pengambil keputusan. Tahapan berikutnya adalah melakukan perbandingan berpasangan untuk mendapatkan segala kemungkinan pertimbangan (judgement) dari semua elemen yang dibandingkan dan menghitung eigen value dan menguji konsistensinya dengan menempatkan bilangan 1 pada diagonal utama, sedangkan di atas dan di bawah diagonal merupakan angka kebalikannya. Apabila hasilnya tidak konsisten, maka dilakukan pengulangan dalam pengambilan data, serta melakukan langkah-langkah tersebut untuk seluruh tingkat hirarki. Tahapan berikutnya adalah menghitung eigen vector (bobot dari tiap elemen) dari setiap matriks perbandingan berpasangan, untuk menguji pertimbangan dalam penentuan prioritas elemen-elemen pada tingkat hirarki terendah hingga tujuan tercapai. Tahapan terakhir adalah memeriksa konsistensi hirarki, apabila nilainya lebih dari $10 \%$, maka penilaian data pertimbangan diulang kembali

\section{HASIL DAN PEMBAHASAN}

\subsection{Hasil}

Berdasarkan hasil pengamatan awal yang dilakukan pada penelitian ini, hasil studi literatur dan hasil wawancara dengan pakar, maka pada penelitian ini disusun lima level hirarki untuk masalah pengelolaan penambangan pasir laut yang berkelanjutan, sebagai berikut :

Level I merupakan tujuan utama (ultimate goal) yang hendak dicapai, yaitu model pengelolaan penambangan pasir laut yang berkelanjutan.

Level II merupakan hirarki dari factor, yaitu prinsip-prinsip yang digunakan untuk mencapai tujuan tersebut dengan dasar pemikiran yang sejalan dengan kerjasama stakeholder pada hirarki ketiga. Adapun yang menjadi factor yang di dalamnya berisi prinsip-prinsip yang perlu mendapat prioritas adalah sosek masyarakat, sumberdaya alam, kebijakan pemerintah, sarana dan prasarana dan pendanaan.
Level III merupakan hirarki dari stakeholder yang harus terlibat dalam upaya mencapai model pengelolaan penambangan pasir laut yang berkelanjutan. Ada beberapa stakeholder yang perlu dibandingkan tingkat kepentingannya yakni pemerintah, masyarakat, institusi lokal, penegak hukum, perguruan tinggi, pengusaha, LSM.

Level IV merupakan hirarki dari tujuan yang berpengaruh untuk dapat mencapai model pengelolaan penambangan pasir laut yang berkelanjutan. Beberapa tujuan yang perlu diprioritaskan adalah reduksi degradasi lingkungan, peningkatan daya saing keindahan Pulau Tunda, perluasan lapangan kerja, minimasi konflik, dan pemulihan ekosistem.

Level V merupakan hirarki dari alternative yang hendak dicapai dalam pengelolaan penambangan pasir laut yang berkelanjutan. Ada beberapa alternatif penting yang harus diprioritaskan menyangkut pengelolaan penambangan pasir laut yakni teknologi penambangan pasir ramah lingkungan, revisi kebijakan penambangan pasir laut, penegakan hukum dan sangsi, rehabilitasi ekosistem laut Pulau Tunda dan insentif dan disinsentif.

Dasar dari penyusunan AHP ini adalah untuk menetapkan skala prioritas dari pengelolaan penambangan pasir laut yang berkelanjutan berdasarkan hirarki yang telah dibentuk.

Berdasarkan hasil analisis terhadap pendapat pakar yang diwawancara pada penelitian ini, didapatkan skala prioritas kepentingan berdasarkan keterlibatan faktor dalam pengelolaan penambangan pasir laut yang berkelanjutan. Adapun keterlibatan faktor dari yang paling penting, hingga yang tidak penting, dapat dilihat pada Gambar 1.

Berdasarkan hasil pengolahan data model AHP, dapat disimpulkan urutan prioritas dari stakeholder dan faktor dalam pengelolaan penambangan pasir laut yang berkelanjutan dapat dilihat lebih jelas pada Gambar 2. 


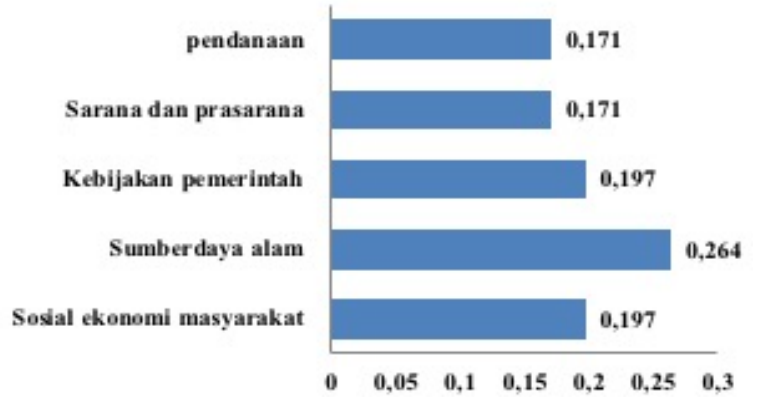

Gambar 1. Hirarki faktor pada pengelolaan penambangan pasir laut yang berkelanjutan.

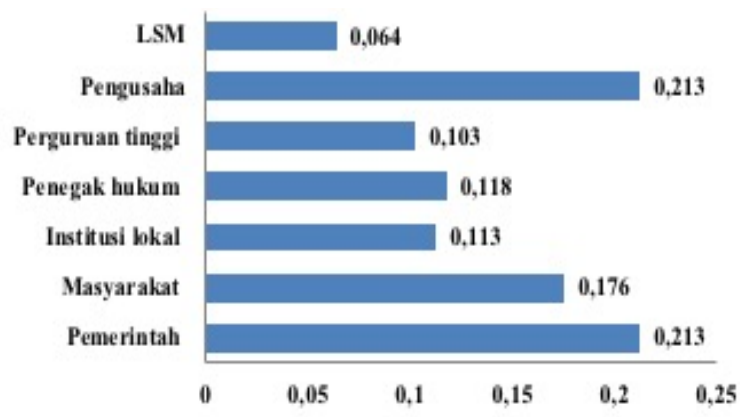

Gambar 2. Hirarki stakeholders pada pengelolaan penambangan pasir laut yang berkelanjutan.

Tahap berikutnya pada analisis AHP adalah menetapkan skala prioritas tujuan pengelolaan penambangan pasir laut agar menjadi berkelanjutan. Berkenaan dengan hal ini ada lima tujuan pada pengelolaan penambangan pasir laut yang berkelanjutan yang harus dinilai kepentingannya.

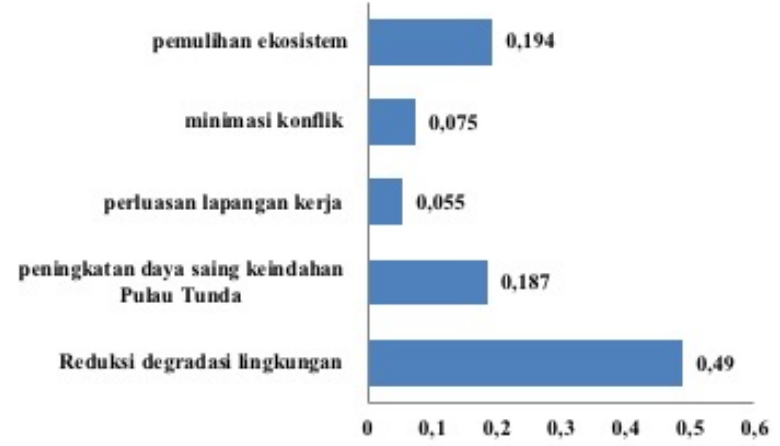

Gambar 3. Hirarki tujuan pada pengelolaan penambangan pasir laut yang berkelanjutan.
Level IV dan Level V masing-masing meliputi hierrarki pengambilan keputusan untuk menetapkan prioritas alternatif kebijakan dari masing-masing tujuan, dan hirarki untuk menentukan prioritas alternatif kebijakan yang paling penting dalam pengelolaan penambangan pasir laut yang berkelanjutan. Hirarki alternatif dari pengelolaan penambangan pasir laut yang berkelanjutan tersebut berada pada Level V.

Setelah ditetapkan prioritas alternatif masing-masing tujuannya, selanjutnya dilakukan penetapan skala prioritas alternatif pengelolaan penambangan pasir laut yang berkelanjutan. Ada lima alternatif dari pengelolaan penambangan pasir laut yang dinilai kepentingannya. Berdasarkan hasil diskusi dengan pakar didapatkan lima alternative. Kelima alternatif pengelolaan penambangan pasir laut yang berkelanjutan tersebut adalah teknologi penambangan pasir ramah lingkungan, untuk revisi kebijakan penambangan pasir laut, penegakan hukum dan sangsi, rehabilitasi ekosistem laut Pulau Tunda serta insentif dan disinsentif. Hasil analisis terhadap pendapat stakeholder diperoleh urutan skala prioritas dari yang terbesar sampai terkecil adalah revisi kebijakan penambangan pasir laut, penegakan hukum dan sangsi, teknologi penambangan pasir ramah lingkungan, rehabilitasi ekosistem laut Pulau Tunda, nsentif dan disinsentif.

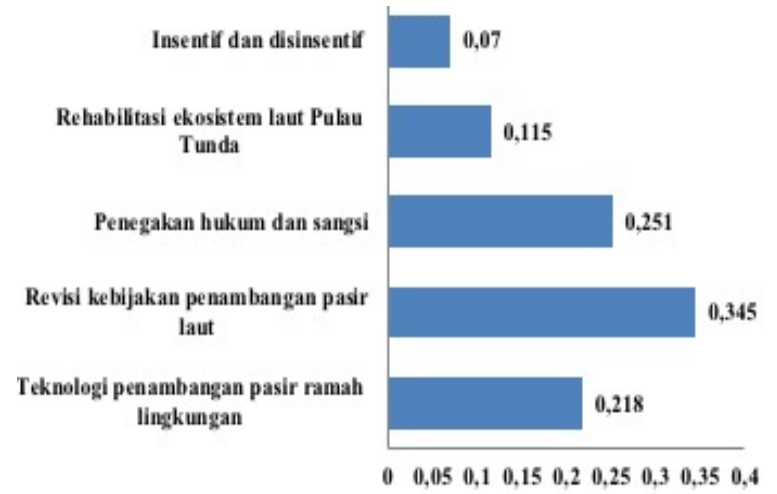

Gambar 4. Hirarki alternatif pengelolaan penambangan pasir laut yang berkelanjutan. 


\subsection{Pembahasan}

Lima level hirarki diperoleh dari penelitian ini yang keseluruhannya ditujukan agar mencapai model pengelolaan penambangan pasir laut yang berkelanjutan. Hirarki AHP ini dapat dilihat lebih jelas pada uraian di bawah ini.

\subsubsection{Hirarki Elemen Faktor}

Lima faktor yang berpotensi dalam pengelolaan penambangan pasir laut yang berkelanjutan yakni sosial ekonomi masyarakat, sumberdaya alam, kebijakan pemerintah, sarana dan prasarana serta pendanaan.

Berdasarkan skala prioritas tersebut di atas (Gambar 1) memperlihatkan bahwa dalam pengelolaan penambangan pasir laut yang berkelanjutan, ternyata faktor sumberdaya alam memiliki pengaruh yang paling dominan. Adapun komponen sumberdaya alam yang paling berpengaruh di sini adalah terdapatnya pasir laut di wilayah studi yang selanjutnya dimanfaatkan, serta keberadaan ekosistem pesisir yang sifatnya sangat fragile, yakni ekosistem terumbu karang, ekosistem padang lamun dan ekosistem mangrove. Ketiga ekosistem tersebut berperan sebagai spawning ground, nursery ground, feeding ground, sebagai tempat berlindung. Menurut Vaske et al. (2015); Murray et al. (2011); Donato et al. (2011); serta Tang et al. (2013), menyatakan ekosistem padang lamun dan mangrove merupakan ekosistem karbon biru yang berperan dalam meminimalisir perubahan iklim.

Komponen kebijakan pemerintah merupakan komponen yang menjadi penentu baik buruknya dan sekaligus penentu kelestarian lingkungan akibat adanya kegiatan eksploitasi pasir laut dan kegiatan pembangunan. Hal tersebut sesuai dengan pernyataan Nietzsche (2000) yang mengatakan bahwa terdapat kekuatan tarik menarik antara obyek dengan kekuatan yang menguasainya. Oleh karena itu maka kekuatan ini dinamakan sebagai kehendak untuk berkuasa (Nietzsche, 2002). Hal ini mengandung arti bahwa pada dasarnya pemerintah sebagai kekuatan yang menguasai sumberdaya alam, termasuk di dalamnya pasir laut, mempunyai kewenangan yang penuh untuk menguasai, dan mengatur agar pengelolaan pasir laut tersebut menjadi berkelanjutan. Menurut Mitchell et al. (2000) agar kebijakan pemerintah dalam pengelolaan lingkungan berhasil diimplementasikan, maka perlu adanya kemitraan antar stakeholder.

Kebijakan pemerintah tertuang dalam Undang-undang Nomor 32 tahun 2009 tentang Perlindungan dan Pengelolaan Lingkungan, yang mengatur tentang pengelolaan lingkungan dalam rangka melestarikan fungsi lingkungan hidup. Oleh karenanya dalam kebijakan tersebut sudah diatur berbagai aspek, mulai dari perencanaan, penataan ruang, pemanfaatan, pengembangan, pemeliharaan dan pemulihan, pengawasan dan pengendalian serta perlindungan lingkungan. Apabila kebijakan tersebut diimplementasikan dengaan baik, maka lingkungan akan lestari. Oleh karena itu maka pemerintah sebagai pemegang kebijakan harus selalu mengawal agar kebijakan tersebut dapat dijalankan dengan baik, sehingga dapat menjaga lingkungan agar tetap lestari.

Hasil analisis ini AHP juga memperlihatkan bahwa aspek kebijakan pemerintah yang terkait dengan pengelolaan penambangan pasir laut yang berkelanjutan, pada umumnya sering mengacu pada pendapatan asli daerah yang dapat mendanai berbagai kegiatan. Dana dibutuhkan sebagai modal untuk membiayai pengadaan dan pengelolaan berbagai, termasuk di dalamnya untuk membiayai pengelolaan penambangan pasir laut, agar menjadi kegiatan yang berkelanjutan. Di lain pihak kebijakan pemerintah merupakan upaya untuk mendukung kegiatan pengelolaan penambangan pasir laut yang berkelanjutan agar dapat dilaksanakan secara lebih jelas yang tertuang dalam peraturan-peraturan. Hal ini sesuai 
dengan pendapat David (2013) bahwa kebijakan dapat dikatakan sebagai satu alat pemerintah untuk mencapai tujuan dan sasaran. Oleh karena itu maka kebijakan pemerintah harus didorong agar dapat diimplementasikan dengan baik, sehingga bukan hanya lingkungan yang menjadi lestari, namun juga sekaligus dapat menyediakan pendanaan untuk berbagai kegiatan, mengingat pada analisis AHP ini pendanaan juga menjadi urutan skala prioritas yang keempat.

Penelitian ini memperihatkan bahwa komponen lain yang juga sangat penting dalam pengelolaan penambangan pasir laut yang berkelanjutan adalah komponen sosial dan ekonomi masyarakat. Komponen sosial yang paling berpengaruh pada pengelolaan penambangan pasir laut yang berkelanjutan adalah persepsi dan partisipasi masyarakat dalam pengelolaan sumber daya alam dan lingkungan, terutama dalam menjaga agar ekosistem fragile di wilayahnya terjaga dengan baik. Menurut Djogo et al. (2003) persepsi adalah proses pencarian informasi yang ditujukan untuk memahami informasi tersebut, yang keudian dapat merubah pandangan seseorang terhadap suatu fenomena yang terjadi, baik yang bersifat konotatif dan denotatif, menolak atau menerima, suka atau tidak suka terhadap obyek yang dihadapinya. Oleh karena itu maka komponen persepsi dan partisipasi masyarakat menjadi salah satu komponen penentu pada terlaksananya pengelolaan penambangan pasir laut yang berkelanjutan.

Persepsi akan terbentuk dari hasil resultante interaksi antara faktor hereditas dengan lingkungan tempat tinggalnya (Thordinke, 1968). Oleh karena itu maka persepsi masyarakat akan timbul setelah masyarakat mengerti akan pentingnya sumberdaya pesisir berupa ekosistem yang fragile di satu sisi dan penambangan pasir laut yang berkelanjutan pada sisi lainnya. Adanya persepsi masyarakat tersebut, selanjutnya, masyarakat akan berupaya secara sukarela untuk mengelola pe- nambangan pasir laut yang berkelanjutan secara bersama-sama. Namun demikian, manusia juga akan memberi persepsi positif terhadap pengelolaan penambangan pasir laut yang berkelanjutan, apabila pengelolaan penambangan pasir laut tersebut dapat memberikan kesejahteraan kepadanya, namun lingkungan tetap lestari. Sebaliknya apabila penambangan pasir laut tersebut tidak mampu meningkatkan kesejahteraan, bahkan merusak lingkungan, yang dirasakan oleh masyarakat berupa makin rendahnya hasil tangkapan dan makin sedikitnya kehadiran wisatawan yang datang ke Pulau Tunda, maka masyarakat cenderung memberi nilai negatif terhadap pengelolaan penambangan pasir laut.

\subsubsection{Hirarki Elemen Stakeholder}

Hirarki ke III adalah hirarki untuk menentukan prioritas stakeholders yang paling berkepentingan terlibat dalam pengelolaan penambangan pasir laut yang berkelanjutan, pada penelitian ini terlihat bahwa stakeholders yang berpotensi dalam pengelolaan penambangan pasir laut yang berkelanjutan adalah sebagai berikut: pemerintah, masyarakat, institusi local, penegak hokum, perguruan tinggi, pengusaha, dan LSM.

Pilihan responden (pakar) (Gambar 2) menempatkan stakeholders pemerintah menjadi prioritas yang pertama dalam pengelolaan penambangan pasir laut yang berkelanjutan. Dasarnya pemerintah merupakan pembuat kebijakan tentang boleh tidaknya melakukan sesuatu. Sebagai contoh mengatur boleh tidaknya dilakukan penambangan pasir serta dengan berbagai aturan agar pelaksanaan penambangan pasir tersebut berjalan dengan baik dan dampaknya terhadap lingkungan menjadi minimal. Oleh karena itu maka pelaksanaan kebijakan tersebut sangat tergantung pada semua tindakan yang dilakukan oleh pemerintah dalam mengawal pelaksanaan penambangan pasir laut. Selain itu juga tergantung pada bagaimana kebijakan itu diinterpretasikan, 
diimplementasikan dan diberlakukan agar penambangan pasir laut menjadi berkelanjutan. Hal tersebut sangat penting dilakukan mengingat wilayah pesisir terutama yang mempunyai ekosistem fragile seperti Pulau Tunda, mempunyai ke khasan baik ditinjau dari aspek biofisik wilayah, ruang pesisir dan laut serta ditinjau dari sumberdayanya. Dalam hal ini adanya intervensi manusia pada wilayah tersebut, dapat mengakibatkan terjadinya perubahan yang signifikan (Hadisumarjo et al., 2015).

Pilihan responden (pakar) menempatkan stakeholders pengusaha sebagai stakeholders yang ke dua, karena pengusahalah yang akan menjadi penentu, apakah akan berupaya tunduk pada aturan yang sudah ditentukan, atau akan melanggar. Pengusaha pula yang akan menentukan apakah kewajiban-kewajiban yang harus dilakukan terkait dengan aspek lingkungan, misalnya kewajiban melaksanakan rencana pengelolaan lingkungan dan melakukan pemantauan terhadap lingkungan seperti yang tercantum pada RKL dan RPL akan dijalankan atau tidak. Oleh karena itu maka sebaik apapun dokumen, atau seburuk apapun dokumen tidak akan ada artinya apabila tidak dibarengi dengan niat baik dari pengusaha untuk melaksanakan pelestarian lingkungan, serta tidak dibarengi dengan pengawasan pelaksanaan RKL dan RPL atau UKL dan UPL oleh pemerintah (Riani et al., 2017).

Pilihan responden (pakar) menempatkan stakeholders masyarakat sebagai stakeholders yang ke tiga pada pengelolaan penambangan pasir laut yang berkelanjutan, karena salah satu penentu baik buruknya kegiatan penambangan pasir, juga ditentukan oleh masyarakat yang terutama tinggal di Pulau Tunda yang seluruhnya menikmati CSR secara langsung (dibagikan bulanan) selama kegiatan penambangan pasir beroperasi. Menurut Race dan Millar (2006), masyarakat merupakan bagian yang penting pada suatu kegiatan, mengingat apabila masyarakat mempunyai keinginan untuk menjaga lingkungannya, maka masyarakat akan berupaya menjaga lingkungannya agar tetap dalam kondisi baik. Selain hal tersebut penambangan pasir telah meningkatkan perekonomian masyarakat secara langsung, apabila mereka hanya ingin mendapatkan uang yang dibagikan tiap bulan, secara berkelanjutan, maka seharusnya mereka sadar bahwa kegiatan penambangan pasir harus dijaga sedemikian rupa agar selalu menjadi berkelanjutan. Menurut Yunus et al. (2013) keterlibatan masyarakat dalam pengelolaan sangat penting, tidak hanya dalam pemanfaatan tetapi juga dalam pemeliharaan. Oleh karena itu maka rasa memiliki serta pemahaman tentang fungsi pengelolaan penambangan pasir laut yang berkelanjutan akan mendorong masyarakat untuk turut serta dalam pengelolaan dan pemeliharaan penambangan pasir laut agar menjadi berkelanjutan. Menurut Djogo et al. (2003) persepsi akan mempengaruhi penolakan atau penerimaan terhadap suatu hal (dalam hal ini terhadap pengelolaan penambangan pasir laut yang berkelanjutan). Oleh karena itu, maka masyarakat harus selalu didorong agar rasa memiliki serta pemahaman tentang fungsi pengelolaan penambangan pasir laut yang berkelanjutan menjadi tinggi.

Adanya pilihan masyarakat sebagai Stakeholders yang turut serta dalam pengelolaan penambangan pasir laut, mengingat masyarakat pesisir adalah sekumpulan masyarakat yang hidup bersamasama, bertempat tinggal di wilayah pesisir, dan selanjutnya membentuk dan memiliki kebudayaan khas, yang terkait dengan ketergantungannya yaitu pada pemanfaatan sumberdaya pesisir (Satria, 2009). Menurut Satria (2015), masyarakat adalah setiap kelompok manusia yang telah lama hidup dan bekerjasama satu sama lain, sehingga dapat mengorganisasi diri dan berpikir tentang dirinya sebagai satu kesatuan sosial dengan batas-batas tertentu. Oleh karena itu maka masyarakat yang merupakan kesatuan sosial akan dapat bekerjasama dengan pemerintah dan pengusaha untuk menjadi 
pengelola penambangan pasir laut yang berkelanjutan. Hal ini diperkuat oleh pernyataan Hoyman and Mc Call (2013) bahwa manusia umumnya bersifat mandiri, sehingga apabila mereka cukup lama hidup bersama, mendiami satu wilayah, memiliki kebudayaan sama dan melakukan sebagian besar kegiatannya di dalam kelompok tersebut; maka masyarakat dapat menjadi Stakeholders pengelola penambangan pasir laut yang berkelanjutan. Menurut Davis and Tisdell (1995), dalam rangka meningkatkan kesadaran lingkungan dan mengurangi dampak kerusakan lingkungan, maka masyarakat perlu dibekali pendidikan yang mumpuni. Mengingat semakin tinggi tingkat pendidikan seseorang, semakin tinggi pula tingkat kematangan berpikir dan pemahaman akan fungsi ekologis, ekonomi dan sosial terhadap sumber daya alam. Hal tersebut sesuai dengan pernyataan Berkes et al. (2000) bahwa usaha konservasi membutuhkan banyak pemahaman dari banyak orang, masyarakat, kelembagaan dan interaksi antar mereka.

\subsubsection{Hirarki Elemen Tujuan}

Responden yang ditemui memilih tujuan pengelolaan penambangan pasir laut yang berkelanjutan utama adalah reduksi degradasi lingkungan (Gambar 3). hal ini terjadi karena penambangan pasir laut yang saat ini dilakukan dianggap belum berkelanjutan. Kondisi ini pada akhirnya diduga menimbulkan masalah berupa terjadinya degradasi lingkungan. Oleh karena itu maka degradasi lingkungan tersebut harus diatasi terlebih dahulu, sehingga dari situ akan tercipta lingkungan yang baik. Dalam arti ekosistem fragile (terumbu karang, lamun dan mangrove) yang ada di perairan Pulau Tunda menjadipulih kembali (peringkat ke dua), dilain pihak ketiga ekosistem fragile tersebut di Pulau Tunda, pada dasarnya menjadi andalan untuk kegiatan wisata di Pulau Tunda. Adanya reduksi degradasi lingkungan dan pemulihan kembali ekosistem di pesisir Pulau Tunda, diharapkan akan memberi dampak positif pada ekosistem pesisir Pulau Tunda menjadi lebih baik, sehingga Pulau Tunda dapat menjadi salah satu tujuan wisata yang mempunyai daya saing yang tinggi (peringkat ke tiga). Di lain pihak pada saat dilakukan survey terlihat bahwa wisatawan yang berkunjung umumnya wisatawan muda dengan rentang usia diperkirakan 18-45 tahun. Menurut Zickuhr (2011), pengunjung pada usia tersebut masuk pada generasi millenial dan Gen $X$ yang bukan hanya gandrung pada teknologi, namun bersifat kurang loyal terhadap sesuatu. Oleh karena itu apabila kondisi Pulau Tunda kurang berkenan, maka tidak mungkin mereka akan mengiklankan hal negative tentang Pulau Tunda, sehingga pengunjung Pulau Tunda berpotensi untuk berkurang.

Pengelolaan penambangan pasir laut, yang setiap beroperasi, memberikan kompensasi kepada masyarakat yang tinggal di Pulau Tunda secara langsung tanpa pandang bulu, diharapkan dapat menjadi salah satu cara untuk meminimasi konflik yang mungkin terjadi di lapangan (peringkat ke empat). Minimalisasi konflik perlu dilakukan, mengingat pada masyarakat manapun potensi terjadinya konflik tinggi. Bahkan pada masyarakat pesisir (nelayan), sekalipun mereka selalu sharing informasi melalui handphone mengenai berbagai kondisi di laut (Saville et al., 2015), terutama jika mereka menemukan sumberdaya yang melimpah atau menemukan adanya penambang pasir di laut, namun pada kenyataannya konflik tidak dapat dihindari. Oleh karena itu maka pilihan ahli pada pengelolaan penambangan pasir laut peringkat ke empat adalah harus meminimalisir terjadinya konflik pada masyarakat nelayan.

Model ini terlihat bahwa perluasan lapangan kerja bagi penduduk setempat, hanya menjadi peringkat ke lima. Mengingat masyarakat Pulau Tunda pada umumnya bermata pencaharian sebagai nelayan. Di lain pihak masyarakat nelayan umumnya mempunyai pendidikan yang rendah, dengan 
keahlian yang dimilikinya relative terbatas pada menangkap ikan di laut, serta susah menerima perubahan (Hadisumarjo et al., 2013). Berdasarkan hal tersebut, maka untuk masyarakat nelayan Pulau Tunda generasi saat ini, perluasan lapangan kerja relative kurang mendukung. Hasil pengamatan penulis terhadap kondisi Pulau Tunda saat ini, memperlihatkan bahwa, apabila akan dilakukan perluasan lapangan kerja, maka perluasan tenaga kerja yang potensinya cukup besar di Pulau Tunda adalah di bidang wisata laut. Pilihan ini didasarkan pada kondisi Pulau Tunda saat ini yang mempunyai pesona keindahan alam bawah laut yang masih cukup diminati, dan wisata pancing yang sudah dipopuler di kalangan hobies memancing.

\subsubsection{Hirarki Elemen Alternatif}

Revisi kebijakan penambangan pasir laut merupakan alternatif utama yang dipilih oleh sebagian besar responden (Gambar 4). Hal ini disebabkan apapun yang dilakukan akan selalu bermuara pada kebijakan yang menjadi landasan utama dari dilakukannya suatu kegiatan. Hal tersebut sesuai dengan pernyataan Riani et al. (2017) bahwa apabila kebijakan yang saat ini ada belum implementatif, maka harus dilakukan berbagai revisi agar kebijakan tersebut menjadi implementatif dan mampu mendukung dilaksanakannya pembangunan berkelanjutan. Selanjutnya dikatakan bahwa dalam rangka membuat kebijakan tersebut menjadi implementatif, maka kebijakan yang dibuat harus tetap mengacu pada Agenda 21 yang menginginkan agar semua pembangunan yang dilakukan di Indonesia berpegang pada prinsip pembangunan yang berkelanjutan, yakni pembangunan yang dapat memenuhi kebutuhan generasi sekarang tanpa mengorbankan generasi yang akan datang untuk dapat memenuhi kebutuhannya. Agar tujuan tersebut tercapai, maka strategi dalam pengelolaan pembangunan tersebut harus mengintegrasikan dan menyeimbangkan antara aspek ekonomi, sosial, dan lingkungan
(Earth Summit Rio de Janeiro, 1992 dan Serageldin, 1996 dan Munasinghe, 1998). Berdasarkan prinsip tersebut, maka pengelolaan yang dilakukan harus mengikuti prinsip tidak boleh mengganggu siklus alam, dan harus dibatasi pada tingkat yang tidak melebihi daya dukung lingkungan (Riani et al., 2017). Oleh karena itu maka pada penambangan pasir laut yang berkelanjutan harus dilakukan campur tangan dari pemerintah, melalui revisi kebijakan yang sudah dibuat, sehingga menjadi lebih implementatif.

Penegakan hukum dan sangsi bagi para pelanggar dan penegakan disiplin bagi aparat yang bertugas untuk melakukan pengawasan terhadap proses penambangan pasir laut, merupakan alternatif kedua yang dipilih oleh sebagian besar responden. Menurut Riani (2012) pada dasarnya pemerintah telah melakukan berbagai upaya penyelamatan lingkungan dengan membuat kebijakan. Namun kadang-kadang kebijakan yang dibuat kurang berhasil menanggulangi terjadinya kerusakan lingkungan akibat kegiatan yang dilakukan. Kondisi tersebut pada umumnya terjadi karena relative rendahnya kesadaran dalam melakukan kewajibannya masing-masing, yang mengakibatkan terjadinya pelanggaran, baik yang dilakukan oleh pelaku kegiatan (SDM), pihak perusahaan, atau bahkan pihak aparat itu sendiri. Oleh karena itu maka penegak hukum harus betul-betul melakukan monitoring terhadap pelaksanaan kegiatan penambangan pasir, serta pengawasan yang semakin diperketat terutama pengawasan terhadap dampak dari kegiatan penambangan pasir laut terhadap ekosistem yang bersifat fragile. Apabila sampai terjadi pelanggaran, maka aparat yang berwajib harus menindak pelanggaran serta harus memberikan sanksi yang tegas bagi pelanggar hukum dan memperketat izin (peninjauan kembali) bagi perusahaan yang terindikasi melanggar aturan yang sudah ditetapkan. Namun apabila perusahaan tersebut menunjukan patuh dan dapat meminimalkan terjadinya kerusakan 
lingkungan, maka disarankan agar pemerintah juga memberi penghargaan pada perusahaan yang mentaatinya.

Teknologi penambangan pasir ramah lingkungan merupakan alternatif ketiga yang dipilih oleh sebagian besar responden. Hal tersebut mengandung arti bahwa melakukan pencarian teknologi penambangan pasir yang ramah lingkungan mutlak harus dilakukan agar penambangan tersebut menghasilkan dampak yang minimal terhadap lingkungan. Dasarnya saat ini sudah ada teknologi yang dianggap ramah lingkungan, yakni teknologi yang menambang pasir dengan kapal isap trailling suction hopper dredger, dengan sistem penambangan crossing system yang di klaim berwawasan lingkungan. Klaim ini didasarkan pada pembentukan batasan terkecil perlindungan alam (minimum environmental protection standard), karena pada sistem ini dibuat alur yang sejajar, baik melintang ataupun membujur blok-blok penambangan. Selain hal tersebut pada saat penambangan tersebut juga dipasang alat untuk membatasi sebaran sedimen berupa tirai yang dipasang silt screen (silt protector) di dalam air untuk mencegah pencemaran akibat kegiatan konstruksi/penambangan di area pantai/laut. Namun kenyataan yang ada masih memperlihatkan adanya gangguan pada ekosistem, terutama ekosistem terumbu karang (Riani et al., 2017). Oleh karena itu maka perlu dicari teknologi lain yang lebih ramah lingkungan dan dapat lebih meminimalkan kerusakan lingkungan. Namun demikian teknologi yang ramah lingkungan ini juga harus tetap diawasi dengan baik, sehingga akan membantu para pekerja dan perusahaan untuk selalu menjaga kedisiplinannya, sehingga kerusakan lingkungan dapat diminimalkan.

\section{KESIMPULAN}

Pengelolaan penambangan pasir laut, faktor dominan yang harus diperhatikan agar menjadi berkelanjutan adalah sumberdaya alam, kebijakan pemerintah, dan sosial ekonomi masyarakat. Stakeholders yang harus diperhatikan agar penambangan pasir laut menjadi berkelanjutan adalah pemerintah, pengusaha, masyarakat dan penegak hukum. Pada penelitian ini ada tiga tujuan yang harus didahulukan agar penambangan pasir laut berkelanjutan, yakni reduksi degradasi lingkungan, pemulihan ekosistem dan peningkatan daya saing keindahan wilayah perairan pulau kecil yang pasirnya ditambang. Prioritas alternatif kebijakan yang paling penting dalam pengelolaan penambangan pasir laut yang berkelanjutan adalah revisi kebijakan penambangan pasir laut, penegakan hukum dan sangsinya, serta teknologi penambangan pasir ramah lingkungan.

\section{DAFTAR PUSTAKA}

Berkes, F., J. Colding, and C. Folke. 2000. Rediscovery of traditional ecological knowledges as adaptive management. Ecol. Appl., 10(5):1251-1262.

Crosby, B.L. 1992. Stakeholder analysis:a vital tool for strategic managers. Technical Notes. http://pdf.usaid. gov/pdf_docs/pnabr482.pdf [Retrieved on 7 Desember 2017].

Davis, D. and C. Tisdell. 1995. economic management of tecreational scuba diving and the environment. $J$. of Environmental Management 48(3): 229-248.

David, F.R. 2013. Strategic management, concept and cases. $14^{\text {th }}$ edition. London. (GB). Pearson Education. Inc. $320 \mathrm{p}$.

Donato, D.C., J.B. Kauffman, D. Murdiyarso, S. Kurnianto, S.M. Stidham, and M. Kanninen. 2011. Mangroves among the most carbonrich forests in the tropics. Nature Geoscience, 4(5):293-297. Doi:10. 1038/ngeo1123.

Golder, B., WWF, and M. Gawler. 2005. Cross-cutting tool stakeholder analysis. http://assets.panda.org/ 
downloads/1_1_stakeholder_analysis 11_01_05.pdf. [Retrieved on 7 Desember 2017].

Hovland, I. 2005. Successful communication a toolkit for researchers and civil society organisations. research and policy in development programme overseas development institute. http:// www.odi.org.uk/sites/odi.org.uk/files/ odi-assets/publications-opinion-files/ 192.pdf. [Retrieved on 7 Desember 2017].

Hadisumarjo, H., R. Saville, dan E. Riani. 2013. Kajian kapasitas nelayan andon di Jakarta Utara. Laporan Penelitian. Suku Dinas Peternakan, Perikanan dan Kelautan. Jakarta Utara. $320 \mathrm{hlm}$.

Hadisumarjo, H., A. Cinnidia, dan Khasanah. 2015. Kajian potensi sumberdaya dan lingkungan pesisir pulau tunda untuk perencanaan minawisata bahari yang berkelanjutan. Laporan Penelitian. Dinas Kelautan, Perikanan, Energi \& Sumberdaya Mineral. Serang. $32 \mathrm{hlm}$.

Hoyman, M. and J.R. Mc Call. 2013. Is there trouble in paradise? The prespective of Galapagos community leaders on managing economic development and environmental conservation through ecotourism policies and the special low of 1998. J. of Ecotourism, 12(1): $33-48$.

Kusumawati. 2008. Penambangan pasir laut di kabupaten serang. studi kasus di perairan Desa Lontar, Kecamatan Tirtayasa. Perencanaan Kota Daerah. UGM. Yogjakarta. $320 \mathrm{hlm}$.

Marimin. 2004. Teknik dan aplikasi pengambilan keputusan kriteria majemuk. Penerbit PT. Gramedia Widiasarana Indonesia. Jakarta. 32 hlm.

Mitchell, B., B. Setiawan, and D.H. Rahmi. 2000. Pengelolaan sumberdaya dan lingkungan. Gadjah Mada University Press. Jogjakarta. $320 \mathrm{hlm}$.
Murray, B.C., W.A Jenkins, S. Sifleet, L. Pendleton, and A.Baldera. 2010. Payments for blue carbon potential for protecting threatened coastal habitats, Policy Brief NI PB 10-05, Nicolas Institute for Environmental Policy Solutions, Duke University. $32 \mathrm{p}$.

Nietzsche, F. 2000. Thus spake zarathustra (Sabda Zarathustra). Sudarmaji dan Ahmad Santoso (Penterjemah). Pustaka Pelajar. Yogyakarta. $32 \mathrm{hlm}$.

Nietzsche, F. 2002. Beyond good and evil: prelude menuju filsafat masa depan. Winarno B.H. (Penterjemah). Ikon. Yogyakarta. $32 \mathrm{p}$.

Parluhutan. 2007. Analisis dampak pertambangan pasir laut terhadap perikanan rajungan di Kecamatan Tirtayasa Kabupaten Serang. Institut Pertanian Bogor. Bogor. 320 hlm.

Prihantono, W.U.J. dan S. Husrin. 2016. Hidrodinamika perairan Teluk Banten pada musim peralihan (Agustus September). Puslitbang Sumberdaya Pesisir dan Laut. KKP. 32 hlm.

Race, D. and J. Millar. 2006. Training manual: sosial and community dimensions of ACIAR Projects. http://aciar.gov.au/files/node/7332/So cial.pdf. [Retrieved on 7 Desember 2017].

Riani, E., M.R. Cordova, dan Z. Arifin. 2017. Pencemaran pesisir dan laut. Departemen Manajemen Sumberdaya Perairan, Fakultas Perikanan dan Ilmu Kelautan IPB. $320 \mathrm{hlm}$.

Riani, E. 2012. Perubahan iklim dan kehidupan biota akuatik (bioakumulasi bahan berbahaya dan beracun dan reproduksi). IPB Press . Bogor. 216 hlm.

Djogo, T., Sunaryo, D. Suhardjito, dan M. Sirait. 2003. Kelembagaan dan kebijakan dalam pengembangan agroforestri. Bahan Ajaran 8. World Agtroforestry Centre (ICRAF) Southeast Asia. Bogor. 320 hlm. 
Saraswati, D. 2005. Analisis sosial ekonomi dan kelembagaan pengelolaan pasir laut di Kabupaten Serang. IPB. 32 hlm.

Satria, A. 2009. Pesisir dan laut untuk rakyat. IPB Press. Bogor. $32 \mathrm{hlm}$.

Satria, A. 2015. Pengantar sosiologi masyarakat pesisir. Yayasan Pustaka Obor Indonesia. Jakarta. $32 \mathrm{hlm}$.

Saville, R., E. Riani, and K. Hatanaka 2015. The role of mobile phone among small scale fishermen for life improvement and community support tool in Indonesian coastal area. $A A C L$ Bioflux, 8(6):846-854.

Tang, Z., J. Shang, and C. Shi. 2013. Estimation of carbon dioxide emissions and spatial variation from tourism accomodation in China. Environmental Engineering and Management J., 12(10): 229-248.

Vaske, J. J., M. H., Jacobs, dan T. K. Espinosa. 2015. Carbon footprint mitigation on vacation: a norm activation model. $J$. of Outdoor Recreation and Tourism, 11: 80-86.

Yunus, M., M.T. Kasnawi, A. Agustang, dan E.L. Poelimbongang. 2013. Social changes in coastal community affected by the conversion of environmental resources. Research on Humanities and Social Sciences. https://www.scribd.com/document/36 2989590/I17cnn. [Retrieved on 27 November 2017].

Zickuhr, K. 2011.Generations and their gadgets. pew research center's internet \& american life project, Washington DC. http://www.pewinternet.org/files/oldmedia//Files/Repor ts/2011/PIP_Generations_and_Gadget s.pdf.
Diterima
: 31 Desember 2017
Direview : 07 Februari 2018
Disetujui : :23 Juli 2018 
